\title{
Expressions of matrix metalloproteinases- 1 and -9 and opioid growth factor in rabbit cornea after lamellar keratectomy and treatment with $1 \%$ nalbuphine
}

\author{
Metaloproteinases de matriz 1, 9, e fator de crescimento opióide, em córneas de coelhos depois de \\ ceratotomia e tratamento com nalbufina a $1 \%$
}

Miguel Ladino Silva ${ }^{1,2}$, Alexandre Pinto Ribeiro ${ }^{3}$, Germana Alegro Silva ${ }^{1}$, Irma Ximena Barbosa Sanchez ${ }^{4}$, Roberta Renzo ${ }^{1}$, Ricardo Uscategui ${ }^{1}$, Tiago Barbalho Lima ${ }^{1}$, Marcela Aldrovani ${ }^{1}$, José Luiz Laus ${ }^{1}$

\begin{abstract}
Purposes: To evaluate the effects of nalbuphine 1\% on the expression of metalloproteinase 1 (MMP-1), metalloproteinase 9 (MMP-9), and opioid growth factor (OGF) in rabbit corneas after lamellar keratectomy.

Methods: The rabbits were assigned to two groups: group nalbuphine ( $G N, n=30)$, which received $30 \mu \mathrm{L}$ of nalbuphine $1 \%$ in 4 daily applications at regular intervals until corneal epithelialization, and group control ( $G C, n=30)$, which received physiological saline solution under the same conditions adopted in GN. The corneas were collected for immunohistochemistry on days 1, 3, 5, 7, and 9 after lamellar keratectomy, and the expressions of MMP-1, MMP-9, and OGF were analyzed.

Results: The expressions of MMP-1 and MMP-9 increased until day 5 of the evaluation, with no differences observed between GN and GC ( $p>0.05)$. On days 7 and 9 , significant reductions were observed in the expression of MMP-1 ( $p<0.01)$, with no differences observed between $G N$ and $G C$ ( $p>0.05)$. The expression of OGF was constant in all periods ( $p>0.05)$, restricted to the corneal epithelium, and there was no difference between the groups ( $p>0.05$ ).

Conclusions: The study results showed that nalbuphine $1 \%$ did not alter the expression patterns of MMP-1, MMP-9, and OGF in rabbit corneas after lamellar keratectomy.
\end{abstract}

Keywords: Cornea; Photorefractive keratectomy; Nalbuphine/therapeutic use; Matrix metalloproteinases; Receptors, opioid; Immunohistochemistry; Animals; Rabbits

\section{RESUMO}

Objetivos: Avaliar os efeitos da nalbufina 1\% sobre a expressão da metaloproteinase 1 (MMP-1), da metaloproteinase 9 (MMP-9) e do fator de crescimento opióide (OGF), em córneas de coelhos submetidas à ceratectomia lamelar.

Métodos: Constituíram-se dois grupos: grupo nalbufina ( $G N, n=30$ ), que recebeu $30 \mu \mathrm{L}$ de nalbufina 1\% em 4 aplicações diárias, a intervalos regulares, até a epitelização corneal; controle ( $G C, n=30)$, que recebeu solução salina nas mesmas condições adotadas no GN. As córneas foram colhidas para imuno-histoquímica decorridos 1, 3, 5, 7 e 9 dias das ceratectomias lamelares, visando a se avaliarem as MMP-1, MMP-9 e OGF.

Resultados: A expressão das MMP-1 e de MMP-9 se elevou até o quinto dia de avaliação, sem diferença entre GN e GC ( $p>0,05)$. Nos dias 7 e 9, observou-se redução significativa na expressão das enzimas $(p<0,01)$, sendo que diferenças não foram observadas entre os grupos $(p>0,05)$. O OGF exibiu imunomarcação constante em todos os períodos $(p>0,05)$, restrita ao epitélio corneal. Não foram encontradas diferenças entre os grupos ( $p>0,05)$.

Conclusões: Com base dos resultados obtidos, há como admitir que a nalbufina 1\% não alterou o padrão de expressão da MMP-1, da MMP-9 e do OGF em córneas de coelhos submetidas à ceratectomia lamelar.

Descritores: Córnea; Ceratectomia fotorrefrativa; Nalbufina/uso terapêutico; Metaloproteinases da matriz; Receptores opióides; Imuno-histoquímica; Animais; Coelhos

\section{INTRODUCTION}

Humans and animals often develop ulcerative keratitis ${ }^{(1)}$, which leads to discomfort and pain due to the activation of nociceptors predominantly located in the superficial layer of the cornea ${ }^{(2)}$. Nalbuphine is an opioid kappa agonist/mu antagonist that produces moderate to severe analgesia(3) and has been used in premedication, surgery, and the postoperative period of obstetric and pediatric practices focused on controlling pain associated with burns ${ }^{(4)}$. Nalbuphine activity depends on the dose, application site, and sex of the patient ${ }^{(5,6)}$. Studies on the analgesic effects of nalbuphine on the cornea have shown that instillation reduces the corneal sensitivity to touch in dogs $^{(5)}$. In contrast, nalbuphine has been demonstrated to sometimes cause damage to the corneal epithelium and stromal fibroblasts ${ }^{(7)}$. It is unclear if nalbuphine can impair the expression of enzymes and growth factors involved in corneal wound healing.
Owing to their importance in maintaining and repairing the epithelium and corneal stroma, matrix metalloproteinases (MMPs) have been widely studied ${ }^{(8,9)}$. MMPs are calcium-dependent zinc-containing endopeptidases involved in inflammation, wound healing, tissue remodeling, and pathological processes ${ }^{(9)}$. These enzymes have been detected in tears and corneal tissue during wound healing and in ocular surface disease ${ }^{(8-10)}$. In corneal ulcers, the combination of the overexpression of MMP-1 and MMP-9 can lead to rapid degradation of corneal extracellular matrix ${ }^{(9)}$. MMP-1 has long been associated with corneal destruction after injury and alkali-induced burns ${ }^{(11)}$. MMP-9 digests denatured collagen, gelatin, and native type IV, V, and VII collagens as well as other extracellular components ${ }^{(12)}$. Higher levels of MMP-9 have been found in the corneal epithelium of patients with cornea edema ${ }^{(13)}$. Matsubara et al. ${ }^{(13)}$ observed that the basement membrane can be dissolved by MMP-9, which facilitates corneal
Submitted for publication: January 12, 2015

Accepted for publication: April 2, 2015

Department of Medicine and Surgery, College of Agricultural and Veterinarian Sciences, Universidade de São Paulo, Jaboticabal, SP, Brazil.

2 College of Agricultural Sciences, University of La Salle, Bogotá, Colombia.

3 Department of Veterinary Clinical Medicine, College of Veterinary and Agricultural Sciences,

Universidade Federal do Mato Grosso, Cuiabá, MT, Brazil.

${ }^{4}$ College of Veterinary Medicine and Animal Science, University of Tolima, Ibague, Colombia.
Funding: This study was supported by FAPESP process number 2009/50082-8 and CNPq process number 300833/2010-5.

Disclosure of potential conflicts of interest: None of the authors have any potential conflicts of interest to disclose.

Corresponding author: José Luiz Laus. Departamento de Clínica e Cirurgia Veterinária. FCAV-UNESP Via de Acesso Prof. Paulo Donato Castellane, s/n, Jaboticabal, SP - 14884-900 - Brazil E-mail: jllaus@fcav.unesp.br

Approved by the Research ethics committee on animals use; protocol number 028793-08. 
ulceration. Knockout mice without MMP-9 have been found to be resistant to corneal epithelial barrier disruption ${ }^{(14)}$. MMP-9 has been shown to be active during remodeling of the corneal stroma after lamellar keratectomy. ${ }^{(8)}$.

Opioid growth factor (OGF) is an endogenous peptide found in different tissues ${ }^{(15)}$. It serves as a growth factor in developing and renewing neoplastic cells and tissues ${ }^{(16)}$. In vitro and in vivo studies have shown that OGF is constitutively expressed in the process of wound healing of rat and rabbit corneal epithelium ${ }^{(17)}$. Regarding domestic species, OGF and its receptor have been identified in dogs, cats, and horses in large concentrations in the corneal epithelium ${ }^{(18)}$. OGF downregulates epithelial cell division and migration in the closing of corneal epithelial abrasions and has a pivotal role in ocular surface repair ${ }^{(17)}$.

The goal of this study was to evaluate the effects of $1 \%$ nalbuphine instillation on the expression of MMP-1, MMP-9, and OGF on rabbit corneas after lamellar keratectomy.

\section{METHODS}

Experiments were performed in accordance with the guidelines set forth by the Association for Research in Vision and Ophthalmology (ARVO) for the use of animals in ophthalmic and vision research and was approved by the Ethics Committee on Animal Use of the Faculty of Agrarian and Veterinary Sciences, UNESP Jaboticabal ( $n \circ 0$ 028793-08). Sixty healthy, adult, male, New Zealand White rabbits with an average weight of $3 \mathrm{~kg}$ were used. The animals were individually kept in proper, clean, and sanitized cages in well-ventilated areas, with a diet of commercial ration and "ad libitum" potable water.

For general anesthesia, an intramuscular injection of $15 \mathrm{mg} / \mathrm{kg}$ of ketamine (Cetamina- S(+); Cristalia Produtos Químicos e Farmacêuticos, Campinas, SP, Brasil) with $0.5 \mathrm{mg} / \mathrm{kg}$ of midazolam (Dormire ${ }^{\circledR}$; Cristalia, São Carlos, SP, Brasil) was used and maintained using isoflurane (Isofluorano; Cristália Produtos Químicos e Farmacêuticos) diluted in oxygen 100\%. The procedures for local anesthesia involved instillation of one drop of proxymetacaine $0.5 \%$ (Proximetacaína-Anestalcon; Alcon, São Paulo, Brasil).

Lamellar axial keratectomy was performed in one of the eyes by using a trephine of 200- $\mu \mathrm{m}$ depth and 6-mm diameter (Trépano for cornea, 6 mm; Steel Inox, São Paulo, SP, Brasil). A $60^{\circ}$ crescent scalpel (Bisturi Crescente Angulado; Ziemer Ophthalmic Systems AG, Switzerland) was used to remove the corneal layer. All interventions were performed by the same surgeon by using a microscope with a magnification of $\times 20$ (MC-M902 ${ }^{\circledR}$; DF Vasconcelos, São Paulo, SP, Brasil).

The rabbits were assigned to two groups: group nalbuphine (GN, $\mathrm{n}=30$ ), which received $30 \mu \mathrm{L}$ of nalbuphine solution 1\% (Cristália Produtos Químicos e Farmacêuticos) instilled 4 times a day at regular intervals for up to 9 days (time of corneal epithelialization) and were clinically monitored by using the fluorescein eye stain test (Fluoresceína em tiras ${ }^{\circledR}$; Ophthalmos, São Paulo, SP, Brasil), and group control (GC, $n=30$ ), which received $30 \mu \mathrm{L}$ of physiological saline solution $(0.9 \% \mathrm{NaCl})$ at the same times and under the same criteria as used for instillation in the GN. For prophylaxis of the infection, all eyes were treated with tobramycin eye drops 0.3\% (Tobrex ${ }^{\circledR}$; Alcon, São Paulo, SP, Brasil), at intervals of $6 \mathrm{~h}$. The animals were not treated orally or parenterally to prevent pain ${ }^{(19)}$.

After 1, 3, 5, 7, and 9 days of lamellar keratectomy, six animals of each group were euthanized by intramuscular injection of $20 \mathrm{mg} / \mathrm{kg}$ of ketamine (Cetamina-S(+); Cristalia Produtos Químicos e Farmacêuticos) and $0.75 \mathrm{mg} / \mathrm{kg}$ of midazolam (Dormire; Cristalia, São Carlos, SP). Lidocaine hydrochloride $2 \%$ (Xylestesin ${ }^{\circledR}$; Cristalia) was administered intrathecally without a vasoconstrictor ${ }^{(20)}$. The entire corneal buttons were harvested, fixed in 10\% buffered formalin, and processed for routine inclusion in paraffin. Cross-sections ( $5 \mu \mathrm{m}$ thick) of the corneal tissue were subjected to immunohistochemistry (IHC).
IHC was performed by using antibodies against MMP-1 (1:200) (Anti-MMP 1 Rabbit pAb ${ }^{\circledR}$; Cabiochem, Darmstad, Germany), MMP-9 (1:100) (Anti-MMP 9(Ab-3) Mouse mAb (56-2A4) ${ }^{\circledR} ;$ Cabiochem), and OGF (1:100) (anti-Enkephalin, Clone NOC ${ }^{\circledR}$; Cabiochem) according to the manufacturer's instructions for each antibody. Dilutions were optimized in our laboratory to eliminate nonspecific staining. Sections were submitted for the blocking of endogenous peroxidase achieved by using a solution of methyl alcohol (Alcohol Metílico Commercial $100 \%{ }^{\circledR}$; Synth, Diadema, SP, Brasil) and hydrogen peroxide (Peroxido de Hidrogenio $50 \%{ }^{\circledR}$; Synth) at a final concentration of $8 \%$. Incubation of the primary antibodies was performed in a moist chamber for $18 \mathrm{~h}$ at a temperature of $4^{\circ} \mathrm{C}$. Immediately thereafter, a secondary antibody (ADVANCE' / HRP, Rabbit/Mouse; DAKO, Carpinteria, USA) was added. Diaminobenzidine (DAB Chromogen ${ }^{\circledR}$ Rabbit/Mouse; DAKO, Carpinteria) was used as a chromogen.

The samples were photographed (Nikon Eclipse E200® ${ }^{\circledR}$ microscope; Nikon, Melville, NY, EUA) (400X) and evaluated in software (Motic Image Plus 2.0; Hong-Kong, China). The expressions of MMP-1, MMP-9, and OGF were established by using semiquantitative IHC scores proposed by Stern et al. ${ }^{(21)}$ (Table 1).

Data were statistically evaluated by using the Kruskal-Wallis' test and Dunn's post-hoc test. GraphPad Prism $4.0^{\circledR}$ software (GraphPad Software, Inc., La Jolla, CA, USA) was used to perform the statistical analyses, and a $\mathrm{p}$-value of $<0.05$ was used to indicate statistical significance.

\section{RESULTS}

The expression of MMP-1 was observed in the interstitial space of the basal epithelial cells, over the basal lamina, and in the corneal stroma occupying approximately $75 \%$ of the evaluated microscopic fields (IHC scores of 5 and 6), with no significant difference observed between the GN and GC until day 5 of the evaluation ( $p>0.05$ ). On days 7 and 9, gradual reductions were observed (IHC scores of 3 and 2 , respectively) in the expression of MMP-1 $(p<0.01)$, with no difference observed between the groups ( $p>0.05$ ). MMP-1 was restricted to the basal region of the corneal epithelium (Figure 1).

There was no significant difference in the IHC scores of MMP-9 between the groups during the evaluations ( $p>0.05$ ). In both the GC and $G N$, a similar pattern of identification to the one found for MMP-1 was observed from day 1 until day 5 of the evaluation ( $p>0.05$ ). On days 7 and 9, significant reductions in MMP-1 were observed $(p<0.001)$ (IHC scores of 2 and 1, respectively), which were restricted to the basal lamina and the interstitial space of epithelial cells near the basal lamina (Figure 2).

Regarding OGF, cytoplasmic localization in the epithelial suprabasal and basal cells was observed. No differences in OGF expression were observed between the periods (IHC scores of 1 and 2 for all) or between the groups ( $p>0.05$ ) (Figure 3 ).

\begin{tabular}{|c|c|}
\hline Índex & Immunostaining \\
\hline $0-0.5$ & Absence of staining: $<10 \%$ \\
\hline 1 & $10 \%-25 \%$ of microscopic fields \\
\hline 2 & $25 \%-50 \%$ \\
\hline 3 & $>50 \%$ \\
\hline 4 & $>75 \%$ \\
\hline 5 & $>95 \%$ \\
\hline
\end{tabular}




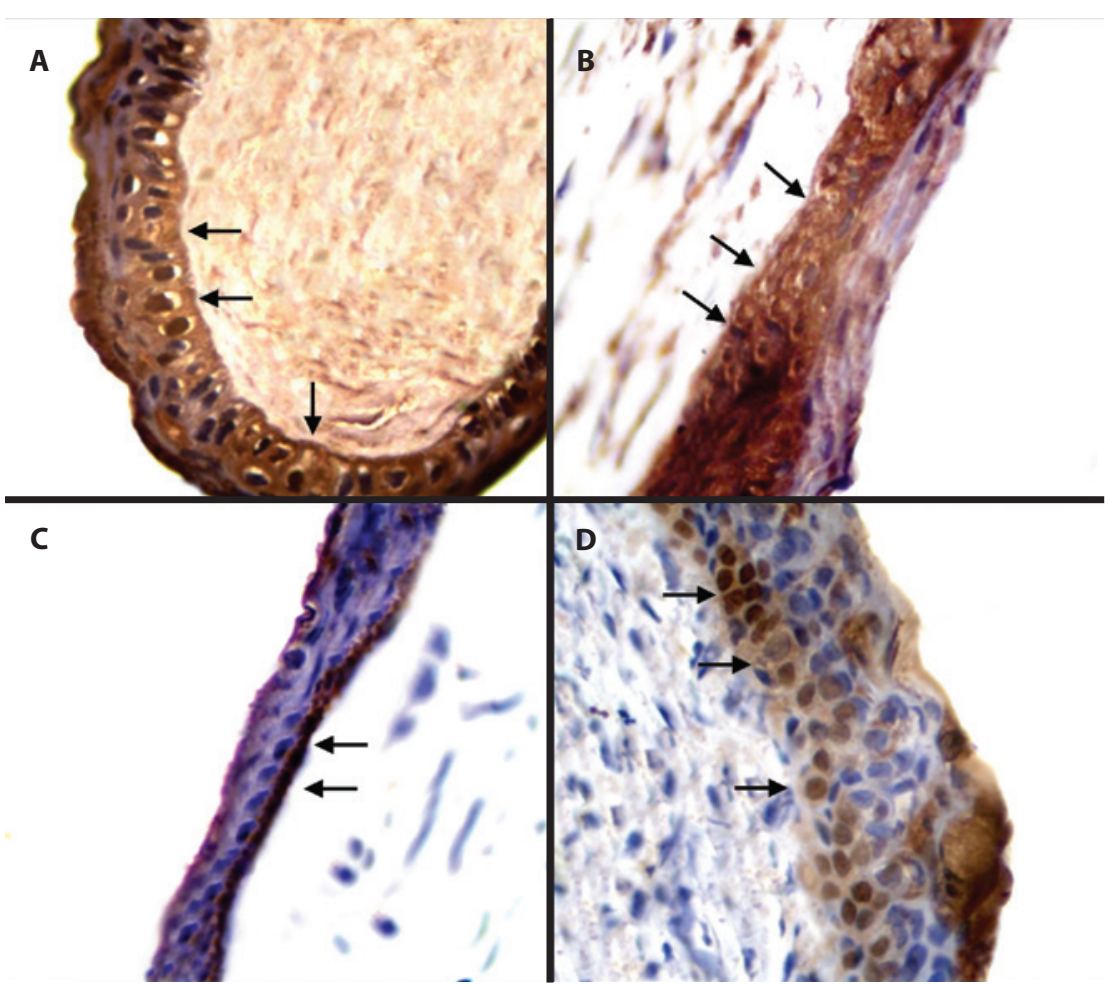

Figure 1. Photomicrographs of corneas from male adult New Zealand White rabbits in group nalbuphine (GN) (B and D) and group control (GC) (A and C) 1 ( $A$ and B) and 9 (C and D) days after lamellar keratectomy. In $A$ and $C$, immunostaining of metalloproteinase- 1 in the basal cells and corneal stroma (arrows) is shown. In $B$ and $D$, a decrease in the immunostaining of metalloproteinase- 1 is observed in the basal cells (arrows). Polymer bound with peroxidase. Magnification, $\times 400$.

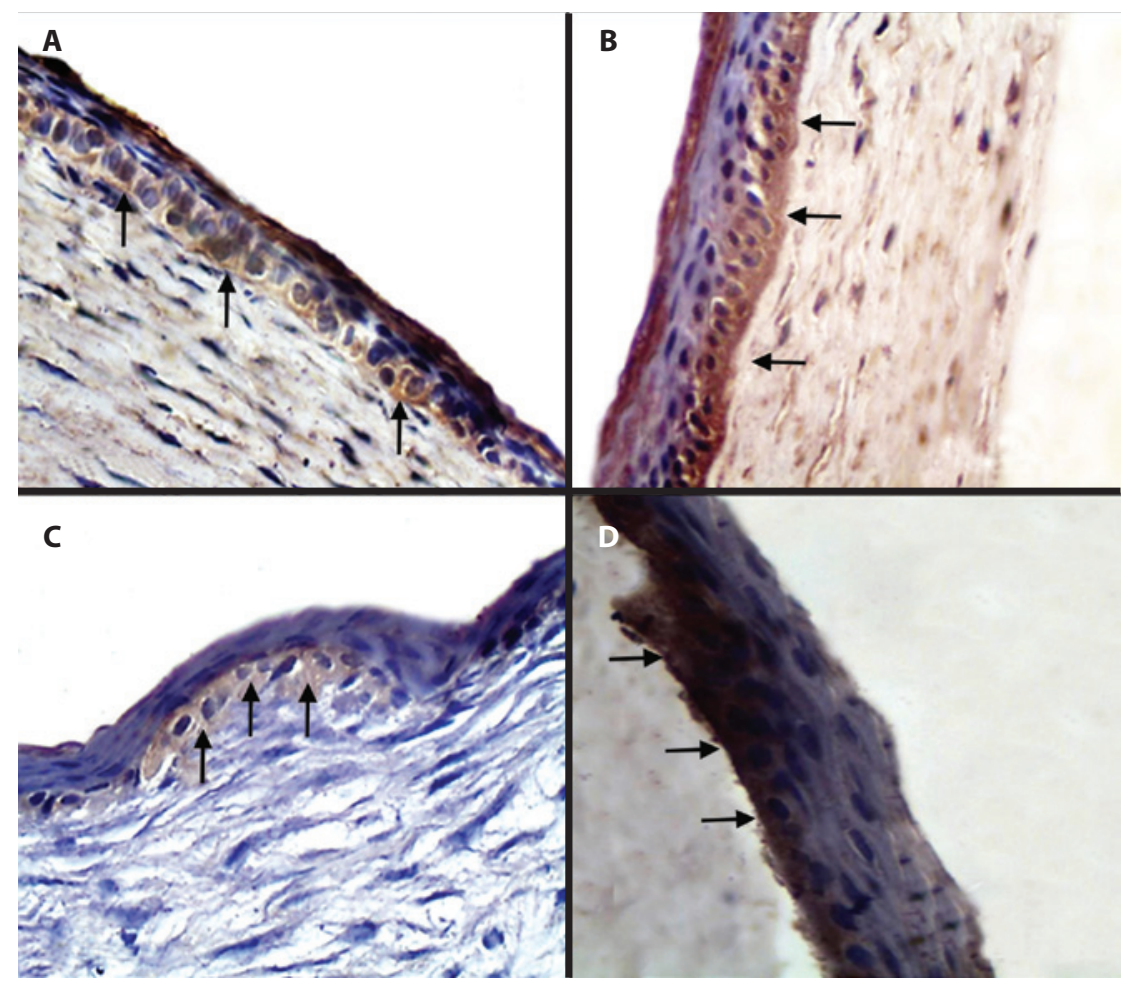

Figure 2. Photomicrographs of corneas from male, adult, New Zealand White rabbits in group nalbuphine (GN) (B and D) and group control (GC) (A and C) 1 ( $A$ and $B$ ) and 9 ( $C$ and D) days after lamellar keratectomy. In A and $C$, immunostaining of metalloproteinase- 9 in the basal cells and corneal stroma (arrows) is observed. In $B$ and $D$, a decrease in the immunostaining of metalloproteinase- 9 is observed in the basal cells (arrows). Polymer bound with peroxidase. Magnification, $\times 400$. 


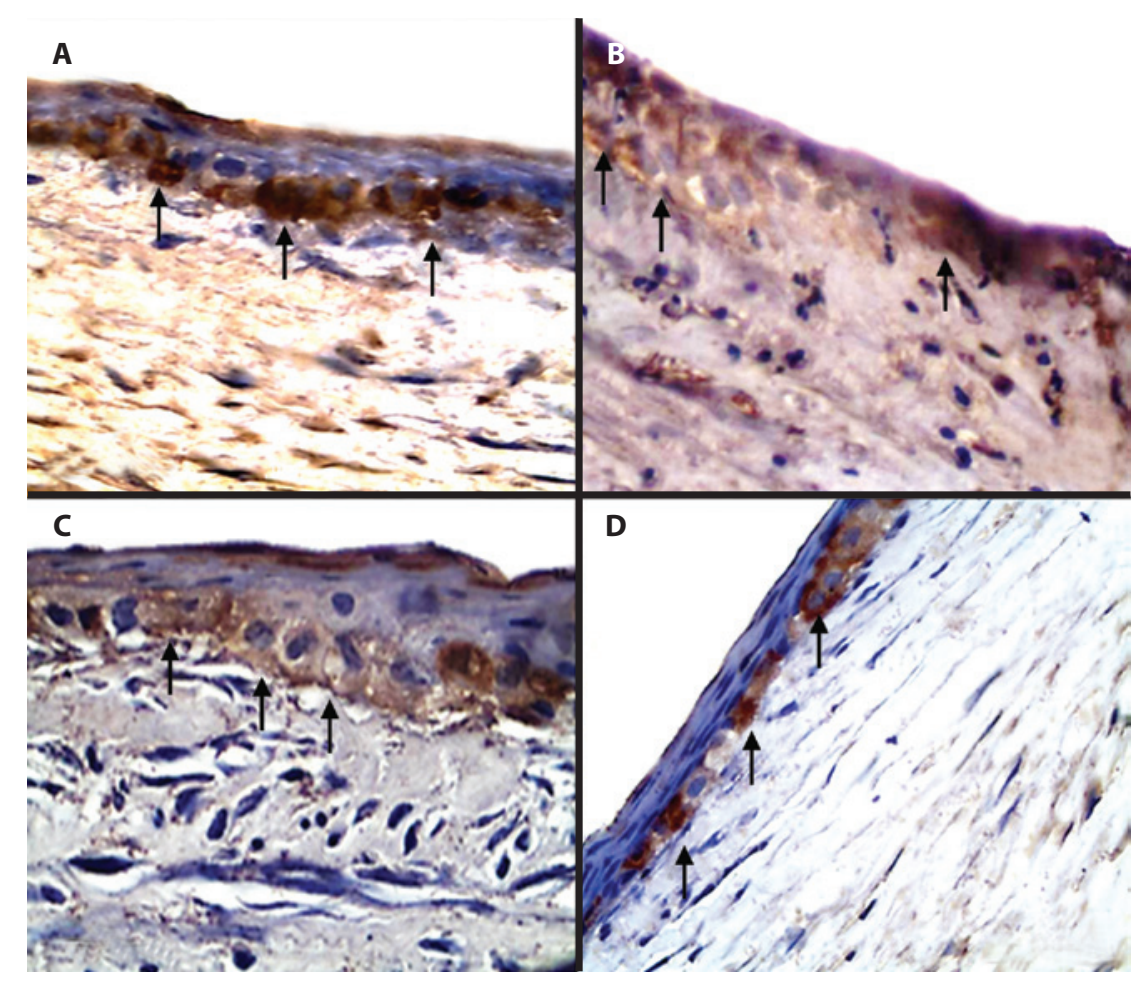

Figure 3. Photomicrographs of corneas from male, adult, New Zealand White rabbits in group nalbuphine (GN) ( $B$ and $D$ ) and group control (GC) (A and C) 1 ( $A$ and $B$ ) and 9 ( $C$ and $D$ ) days after lamellar keratectomy. In $A$ and $\mathrm{B}$, immunostaining of opioid growth factor in the basal cells and intracytoplasm (arrows) and absence of the opioid growth factor in the stroma are observed. In C and D, staining of the opioid growth factor indicates similar concentrations in the two groups. Polymer bound with peroxidase. Magnification, $\times 400$.

\section{DISCUSSION}

MMPs are zinc-dependent endopeptidases secreted by keratocytes, epithelial cells, and other cell types ${ }^{(9)}$. In this study, greater IHC scores were observed in the corneal epithelium near the border of the lesion, in accordance with the results reported by Ribeiro et al. ${ }^{(22)}$. In the present research, MMP-1 and MMP-9 were detected in the basal membrane and superficial stroma. A similar finding was reported by Ye and Azar ${ }^{(23)}$. In contrast, Mulholland et al. ${ }^{(8)}$ found MMP only in the corneal sub-epithelial region; this could be related to differences in the $\mathrm{IHC}$ technique used. $\mathrm{IHC}$ results depend on the type of detection procedure and the antibody used (monoclonal versus polyclonal).

The IHC technique used in the present study cannot discriminate between the active and inactive forms of MMPs ${ }^{(22)}$; however, it is able to detect different expression patterns of these proteases. Additional studies should be conducted in this area in the future. Several procedures are available to quantify MMPs, and all have advantages and limitations. Western blotting and zymography are used to evaluate expression at the protein level(24). SDS-PAGE substrate zimography and reverse zymography allow only measurement of the relative activities of MMPs because pure preparations of MMP are often unavailable to permit standardization ${ }^{(24)}$. In situ zimography is a complementary procedure for $\mathrm{IHC}$ and reverse zimography; however, it may be difficult to discriminate between different MMPs classes ${ }^{(24)}$. With in situ zymography, only active MMPs are detected by visualizing areas where they have digested the substrate, which also occurs with serine, cysteine, or aspartic proteinases ${ }^{(24)}$.

There are no previous reports about the effects of opioid agonists/antagonist drugs on the expression of MMPs. Here, decreases in the expressions of MMP-1 and MMP-9 in the lesion were observed on days 7 and 9, respectively, in the GC and GN. Clinical parameters and epithelization times in rabbit corneas treated under the same experimental protocols as used here have been reported in a previous study ${ }^{(19)}$.

Ribeiro et al. (22) using IHC and zymography showed that morphine (pure opioid agonist) increased the expression of MMP-9 in corneas after lamellar keratectomy. Here, nalbuphine produced no alterations in MMP-1 or MMP-9. A study involving a MCF-7 breast cancer cell line showed the inhibitory effects of MMP induced by morphine ${ }^{(25)}$, which is in contrast with the results obtained with nalbuphine in the present study. In MCF-7 cells, however, the attenuation of MMP secretion by opioids was not mediated by opioid receptors but was under the control of the nitric oxide system ${ }^{(25)}$.

Hormonal factors must be considered when evaluating the effects of opioid analgesics. In this research, only male rabbits were used to eliminate eventual biases related to sex. Sexually dimorphic kappa-mediated antinociception has been observed in antithetical antinociceptive/nociceptive responsiveness of females versus males to kappa agonists/ antagonists ${ }^{(26)}$. Apparently, selective kappa agonists produce greater antinociceptive effects in males ${ }^{(27)}$. In contrast, women have greater analgesic effects from the mixed mu/kappa ligands: pentazocine, nalbuphine, and butorphano( ${ }^{(28)}$. Interactions of opioids with estrogen are poorly understood and should be further investigated to provide insights into sex differences in analgesia.

In the present study, OGF was detected in epithelial suprabasal and basal cells. This finding is consistent with those obtained in other studies $^{(15)}$. Even with kappa agonist/mu antagonist action, nalbuphine did not alter OGF expression. In the present study, it was also found that the agonist fraction of nalbuphine did not interfere with the expression of endogenous peptides. In a previous study ${ }^{(29)}$, pharmacological intervention with opioid antagonist naltrexone (NTX; $30 \mathrm{mg} / \mathrm{kg}$, twice daily) was related to the inhibition of OGF and delay in corneal repair of diabetic rats. A study conducted in inflammatory models in 
the abdominal cavity demonstrated that local application of morphine increased the concentration of endogenous opioid peptides ${ }^{(30)}$.

In conclusion, results of the present study showed that instillation of nalbuphine $1 \%$ did not alter the immunohistochemical expression patterns of MMP-1, MMP-9, and OGF in rabbit corneas after lamellar keratectomy.

\section{REFERENCES}

1. Galera PD, Laus JL, Oriá AP. Afecções da túnica fibrosa. In: Laus JL, editor. Oftalmologia clínica e cirúrgica em cães e em gatos. São Paulo: Roca; 2009. p.69-96.

2. Müller LJ, Marfurt CF, Kruse F, Tervo TM. Corneal nerves: structure, contents and function. Exp Eye Res. 2003;76(5):521-42. Erratum in: Exp Eye Res. 2003;77(2):253.

3. Hoskin PJ, Hanks GW. Opioid agonist-antagonist drugs in acute and chronic pain states. Drugs. 1991:41(3):326-44.

4. Liao CC, Chang CS, Tseng CH, Sheen MJ, Tsai SC, Chang YL, et al. Efficacy of intramuscular nalbuphine versus diphenhydramine for the prevention of epidural morphine-induced pruritus after cesarean delivery. Chang Gung Med J. 2011;34(2):172-8.

5. Aquino S, Van der Woerdt A, Eaton, S. The effect of topical nalbuphine on corneal sensitivity in normal canine eyes. Vet Ophthalmol. 2005:8(6):450.

6. Lomas LM, Barrett AC, Terner JM, Lysle DT, Picker MJ. Sex differences in the potency of $\mathrm{k}$ opioids and mixed-action opioids administered systemically and at the site of inflammation against capsaicin-induced hyperalgesia in rats. Psychopharmacology (Berl). 2007;191(2):273-85.

7. Spatola RA, Thangavelu M, Upadhyayula V, Lee S, Phelps MA, Chandler HL. Analysis of the transport of and cytotoxic effects for nalbuphine solution in corneal cells. Am J Vet Res. 2012;73(12):1987-95.

8. Mulholland B, Tuft SJ, Khaw PT. Matrix metalloproteinase distribution during early corneal wound healing. Eye (Lond). 2005;19(5):584-8.

9. Brooks DE, Olliver FJ. Matrix metalloproteinase inhibition in corneal ulceration. Vet Clin North Am Small Anim Pract. 2004:34(3):611-22.

10. Ebrahem Q, Chaurasia SS, Vasanji A, Qi JH, Klenotic PA, Cutler A, et al. Cross-talk between vascular endothelial growth factor and matrix metalloproteinases in the induction of neovascularization in vivo. Am J Pathol. 2010;176(1):496-503.

11. Gordon JM, Bauer EA, Eisen AZ. Collagenase in human cornea. Arch Ophthalmol. 1980:98(2):341-5.

12. Predović J, Balog T, Marotti T, Gabrić N, Bohac M, Romac I, et al. The expression of human corneal MMP-2, MMP-9, proMMP-13 and TIMP-1 in bullous keratopathy and keratoconus. Coll Antropol. 2008;32 Suppl 2:15-9

13. Matsubara M, Zieske JD, Fini ME. Mechanism of basement membrane dissolution preceding corneal ulceration. Invest Ophthalomol Vis Sci. 1991;32(13):3221-37.
14. Pflugfelder SC, Farley W, Luo L, Chen LZ, de Paiva CS, Olmos LC, et al. Matrix metalloproteinase-9 knockout confers resistance to corneal epithelial barrier disruption in the experimental dry eye. Am J Pathol. 2005;166(1):61-71.

15. Zagon IS, Ruth TB, Leure-duPree AE, Sassanib JW, Mclaughlin PJ. Immunoelectron microscopic localization of the opioid growth factor receptor (OGFr) and OGF in the cornea. Brain Res. 2003;967(1-2):37-47.

16. Zagon IS, Mclaughlin PJ. Opioids and differentiation in human cancer cells. Neuropeptides. 2005;39(5):495-505.

17. Zagon IS, Sassani JW, McLaughlin PJ. Re-epithelialization of the rat cornea is accelerated by blockade of opioid receptors. Brain Res. 1998;798(1-2):254-60.

18. Robertson SA, Andrew SE. Presence of opioid growth factor and its receptor in the normal dog, cat and horse cornea. Vet Ophthalmol. 2003;6(2):131-4.

19. Silva ML, Piso DY, Ribeiro AP, Laus JL. Topical $1 \%$ nalbuphine on corneal sensitivity and epithelialization after experimental lamellar keratectomy in rabbits. Cienc. Rural. 2012:42(4):669-84.

20. Thomas RD, Behbehani MM, Coyle DE, Denson DD. Cardiovascular toxicity of local anesthetics: an alternative hypothesis. Anesth Analg. 1986;65(5):444-50.

21. Stern ME, Gao J, Beuerman RW, Farley W, Zhuo L, McDonnell P. Effects of fourth-generation fluoroquinolones on the ocular surface, epithelium, and wound healing. Cornea. 2006;25(9):S12-S24.

22. Ribeiro AP, Silva ML, Araújo RL, Ferrucci DL, Mineo T, Thiesen R, et al. Expression of matrix metalloproteinases, type IV collagen, and Interleukin-10 in rabbits treated with morphine after lamellar keratectomy. Vet Ophthalmol. 2012;15(3):153-63.

23. Ye HQ, Azar DT. Expression of gelatinases A and B, and TIMPs 1 and 2 during corneal wound healing. Invest Ophthalmol Vis Sci. 1998;39(6):913-21.

24. Snoek-Van Beurden PA, Von Den Hoff JW. Zymographic techniques for the analysis of matrix metalloproteinases and their inhibitors. Biotechniques. 2005;38(1):73-83.

25. Gach K, Szemraj J, Wyrębska A, Janecka A. The influence of opioids on matrix metalloproteinase-2 and -9 secretion and mRNA levels in MCF-7 breast cancer cell line. Mol Biol Rep. 2011;38(2):1231-6.

26. Gintzler AR, Liu NJ. Importance of sex to pain and its amelioration; relevance of spinal estrogens and its membrane receptors. Front Neuroendocrinol. 2012;33(4):412-24.

27. Rasakham K, Liu-Chen LY. Sex differences in kappa opioid pharmacology. Life Sci. 2011;88(1-2):2-16.

28. Gear RW, Miaskowski C, Gordon NC, Paul SM, Heller PH, Levine JD. Kappa opioids produce significantly greater analgesia in women than in men. Nat Med. 1996;2(11): 1248-50.

29. Zagon IS, Jenkins JB, Sassani JW, Wylie JD, Ruth TB, Fry JL, et al. Naltrexone, an opioid antagonist, facilitates reepithelialization of the cornea in diabetic rat. Diabetes. 2002; 51(10):3055-62

30. Chadzinska M, Scislowska-Czarnecka A, Pierzchala-Koziec K, Plytycz B. Met-enkephalin involvement in morphine-modulated peritonitis in swiss mice. Mediators Inflamm. 2005:2005(2):112-7.

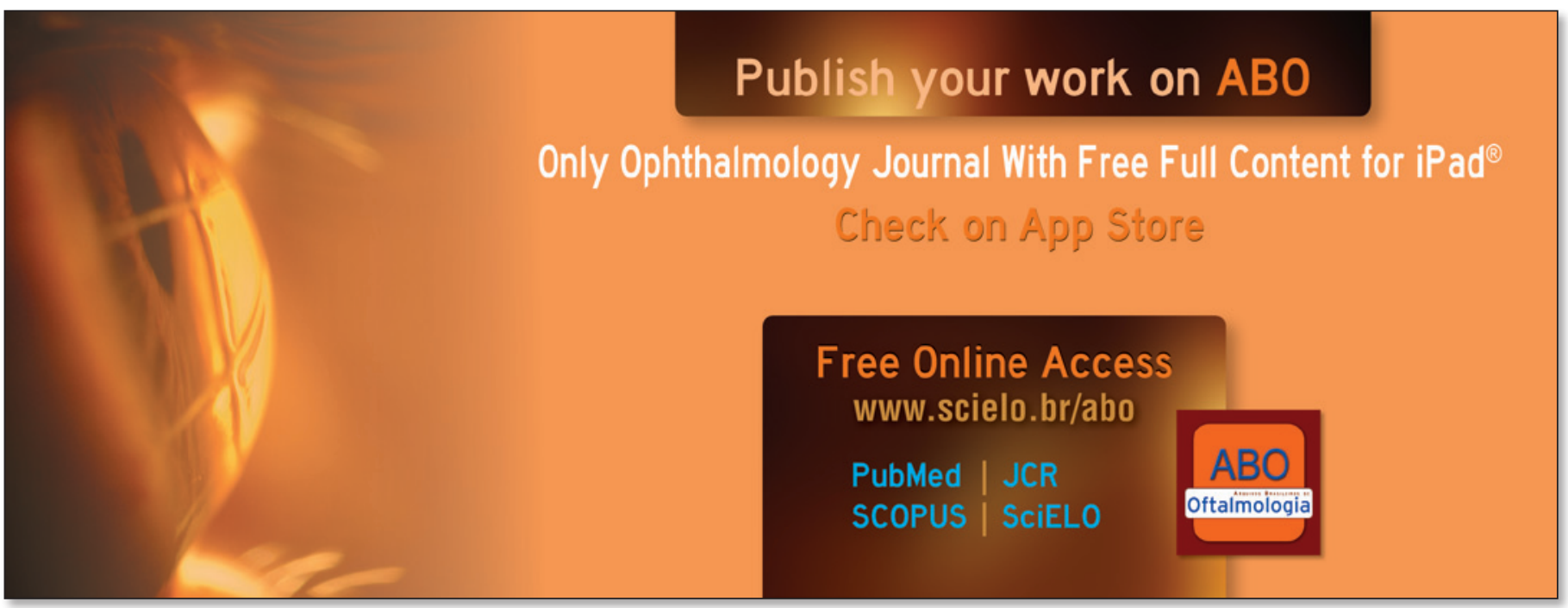

